\title{
Activity and subcellular distribution of mouse uterine alkaline phosphatase during pregnancy and pseudopregnancy
}

\author{
R. N. Murdoch, D. J. Kay and M. Cross \\ Department of Biological Sciences, University of Newcastle, Newcastle, \\ New South Wales 2308, Australia
}

\begin{abstract}
Summary. The biochemical assay of alkaline phosphatase in the uterus of mice revealed a 13-fold increase in the activity of the enzyme during the peri-implantation period with a relatively short-lived maximum being reached on Day 7 of pregnancy. A similar increase in the activity of the enzyme occurred between Days 5 and 7 of pseudopregnancy in uterine horns of mice receiving a deciduoma-inducing stimulus on Day 4. The presence of factors in uterine homogenates which could possibly modify the activity of the enzyme could not be detected. Low and unaltered levels of alkaline phosphatase activity were found in the blood serum of mice between Days 1 and 10 of pregnancy, suggesting that no appreciable entry of the uterine enzyme into the circulation occurs in this species. Alkaline phosphatase activity in the uterine homogenates was associated with particulate fractions sedimented during centrifugation at 500,10000 and $105000 \mathrm{~g}$, and only about $29 \%$ of the activity was associated with the cytosol fraction. The subcellular distribution of the enzyme activity was the same in decidualized and non-decidualized horns. The association of the enzyme with the particulate material in uterine cells was considered to involve lipoprotein membranes because treatment of homogenates with $0.2 \%(\mathrm{v} / \mathrm{v})$ Triton X-100 solubilized the enzyme without affecting its catalytic activity.
\end{abstract}

\section{Introduction}

Changes in the activity of uterine alkaline phosphatase (orthophosphoric monoester phosphohydrolase, EC 3.1.3.1) during early pregnancy have been described in a number of mammalian species, including the mouse (Finn \& Hinchliffe, 1964; Finn \& McLaren, 1967; Smith, 1973), rat (Christie, 1966; Manning, Steinetz \& Giannina, 1969), cow (Leiser \& Wille, 1975), rabbit (Hafez \& White, 1967; Murdoch, 1970, 1972), and sheep (Hafez \& White, 1968; Murdoch, 1970), but no precise physiological role has yet been assigned to the enzyme in any tissue or organ in which it occurs (Fernley, 1971). The enzyme in the uterus, however, has been implicated in metabolic transformations concerned with the nutrition of the developing preimplantation embryo (Murdoch, 1970) and in the induction of the decidual cell reaction (Finn \& Hinchliffe, 1964; Hall, 1969; Manning et al., 1969). There is also little knowledge of the nature and mechanism of action of processes responsible for the regulation of alkaline phosphatase activity in the uterus. The elucidation of these processes could yield important information about implantation and uterine factors which influence early embryonic development.

Previous studies of alkaline phosphatase in the uterus of the pregnant and pseudopregnant mouse, involving histochemical techniques to demonstrate the location and activity of the enzyme, have clearly associated the enzyme with the deciduoma reaction (Finn \& Hinchliffe, 1964; Finn \& McLaren 1967; Hall, 1969; Smith, 1973). However, to our knowledge there are no reports in the literature on the biochemistry and subcellular distribution of the enzyme in the uterus of this species. We have therefore studied both of these aspects of alkaline phosphatase activity in the pregnant mouse to determine more precisely the magnitude of the response and the time at which maximal activity is achieved.

\section{Animals}

\section{Materials and Methods}

Randomly bred albino female mice, of the QS strain and aged 8-12 weeks, were used in all experiments; they were nulliparous unless otherwise indicated. The mice were housed in a controlled 
environment room kept at $25^{\circ} \mathrm{C}$ and in which the light period extended from 07:00 to 20:00 h each day. The animals were permitted unlimited access to Mecon mouse cubes (Fidelity Feeds, N.S.W.) and fresh water.

Pregnancy or pseudopregnancy was induced by pairing the females with intact or vasectomized males respectively. The females were examined for copulation plugs each morning and the day of finding a plug was designated as Day 1 or the 1st day of pregnancy or pseudopregnancy. Deciduomata were induced in the left uterine horns of pseudopregnant mice by the intraluminal injection of $30 \mu \mathrm{l}$ peanut oil, as described by Finn \& Hinchliffe (1964), after anaesthesia with pentobarbitone sodium (Nembutal). The oil injection was administered at the uterotubal junction between 15:00 and 16:30 $\mathrm{h}$ on Day 4 of pseudopregnancy. The mice were killed by cervical dislocation at 09:00 h on Days 5 to 10 of pseudopregnancy, on each day of pregnancy, on the day of parturition, and on each day for about the 1st week post partum. During the post-partum period, litters (6-11 young) were permitted to remain with and suck their mothers until the time of autopsy.

\section{Preparation of uterine tissue, blood serum and other organs}

At autopsy the uteri were removed and dissected free of fatty and connective tissue and of the attached oviducts and cervix. All subsequent processing was performed at $4^{\circ} \mathrm{C}$. The reproductive tracts of mice on Days 1-5 of pregnancy were rinsed with $0 \cdot 154 \mathrm{M}-\mathrm{NaCl}$ and the flushings were examined microscopically for fertilized eggs. The uteri from mice at all other stages of pregnancy were carefully opened and all embryonic tissue, with the exception of the placenta, was removed by dissection and rinsing with $0 \cdot 154 \mathrm{M}-\mathrm{NaCl}$. Care was taken to leave the placentae intact to avoid the possibility of removing decidualized stromal tissue. The uteri were dried between pieces of filter paper, minced thoroughly with fine scissors and forceps, weighed, homogenized in 10 parts of $0.25 \mathrm{M}$-sucrose with a ground-glass Potter-Elvehjem homogenizer, and then centrifuged at $400 \mathrm{~g}$ for $5 \mathrm{~min}$. The supernatant was retained for alkaline phosphatase and protein analyses.

Uteri from pseudopregnant mice were also prepared by this method with the exception that the right and left uterine horns were individually excised at the time of autopsy and processed separately.

Various organs, including the spleen, liver, kidneys, small intestine and uterus, were obtained from female mice, designated as non-pregnant, on the day of mating with vasectomized males and were prepared for the assay of alkaline phosphatase activity and protein as described above for pregnant and pseudopregnant uteri. The small intestine was flushed twice with $10 \mathrm{ml} 0 \cdot 154 \mathrm{M}-\mathrm{NaCl}$ to remove the contents before further processing.

Blood was collected from the non-pregnant and pregnant mice (on Days 1 to 10) by means of heart puncture at the time of autopsy. The serum obtained after centrifugation $\left(4^{\circ} \mathrm{C}, 30 \mathrm{~min}, 1000 \mathrm{~g}\right)$ was retained for alkaline phosphatase and protein analyses.

\section{Centrifugation of uterine homogenates}

The left (decidualized) and right (non-decidualized) uterine horns of Day-7 pseudopregnant mice and the entire uterus from Day-7 pregnant mice were homogenized separately in 20 parts of $0.25 \mathrm{M}$ sucrose until $95 \%$ or more of the cells were ruptured as judged by examination under a phase-contrast microscope. The appropriate tissues from 3 or 4 mice were pooled to provide sufficient material for study. Each homogenate was divided into three portions of equal volume and centrifuged either at $500 \mathrm{~g}$ for $5 \mathrm{~min}, 10000 \mathrm{~g}$ for $30 \mathrm{~min}$, or $105000 \mathrm{~g}$ for $1 \mathrm{~h}$ at $4^{\circ} \mathrm{C}$. Centrifugations at 500 and $10000 \mathrm{~g}$ were performed in a SS-34 rotor with a RC2-B Sorvall centrifuge. Centrifugal forces of $105000 \mathrm{~g}$ were achieved by using a type A-321 rotor in a Damon B-60 ultracentrifuge. After centrifugation, the supernatants were aspirated into clean test-tubes and held at $4^{\circ} \mathrm{C}$. The sediment in each centrifuge tube was redispersed in a volume of $0.25 \mathrm{M}$-sucrose equal to that of the supernatant aspirated and also held at $4^{\circ} \mathrm{C}$. Alkaline phosphatase activity was assayed in all supernatant and sediment fractions and compared with that occurring in the homogenates before centrifugation.

Triton X-100 (Calbiochem) was added to some of the uterine homogenates at a concentration of $0.2 \%(\mathrm{v} / \mathrm{v})$ and incubated at $37^{\circ} \mathrm{C}$ for $1 \mathrm{~h}$ with gentle agitation. After incubation, the samples were centrifuged at $10000 \mathrm{~g}$ or $105000 \mathrm{~g}$ as described above and alkaline phosphatase activity was assayed in the supernatant and sediment fractions. 
Alkaline phosphatase and protein analyses

Alkaline phosphatase activity was assayed by the spectrophotometric measurement of hydrolysis of $p$-nitrophenylphosphate as described previously (Murdoch, 1972). Unless otherwise stated, $0.1 \mathrm{ml}$ of the enzyme preparation, appropriately diluted in $0.25 \mathrm{M}$-sucrose, was incubated in $1.0 \mathrm{ml}$ of a mixture containing $50 \mathrm{~mm}$-glycine buffer $(\mathrm{pH} 10.5), 0.5 \mathrm{mM}^{-\mathrm{MgCl}_{2}} \cdot 6 \mathrm{H}_{2} \mathrm{O}$, and $6.0 \mathrm{~mm}$-substrate. After incubation at $37^{\circ} \mathrm{C}$ for $30 \mathrm{~min}, 10 \mathrm{ml} \mathrm{0.02} \mathrm{N-NaOH}$ were added and the extinction at $405 \mathrm{~nm}$ was measured against a reagent blank without enzyme. Enzyme activities were expressed as $\mu \mathrm{mol} p$ nitrophenol liberated from the hydrolysis of substrate at $37^{\circ} \mathrm{C}$ per mg protein, unless otherwise indicated, and were calculated using standards of analytical reagent grade $p$-nitrophenol.

The protein concentration of samples was determined by the method of Lowry, Rosebrough, Farr \& Randall (1951) by using standards of bovine serum albumin.

All analytical determinations were performed in duplicate and were replicated 4 to 6 times with different preparations on each occasion. When necessary, Student's $t$ test was employed to assess the significance of results.

\section{Results}

\section{Changes during pregnancy and early post partum}

The changes in uterine alkaline phosphatase activity and uterine weight are illustrated in Text-fig. 1. Alkaline phosphatase activity decreased significantly $(P<0.01)$ between Days 1 and 3 of pregnancy and then increased to a maximum on Day 7 before rapidly decreasing to reach, on Day 14 , values similar to those recorded before the Day 5 increase. Activity remained low and did not change significantly after Day 14 of pregnancy.

Except for the period between Days 1 and 3 of pregnancy when the weight of the uterus decreased slightly $(P<0.05)$, the pattern of alkaline phosphatase activity in the uterus did not coincide with the uterine weight changes. In general, uterine weight increased with advancing pregnancy and reached a maximum near the time of parturition. After parturition, the weight rapidly decreased and on Day 8 post partum was similar to that recorded in the very early stages of pregnancy.

The activity of alkaline phosphatase in the blood serum was low compared with that of the uterus and other organs examined (see Table 1) and did not change significantly between Days 1 and 10 of pregnancy, indicating that the Day-7 peak of uterine activity of the enzyme was not reflected in the serum.

Table 1. Alkaline phosphatase activities in the blood serum, uterus and other organs of the mouse

\begin{tabular}{lcccccc}
\hline $\begin{array}{c}\text { Blood } \\
\text { serum }\end{array}$ & $\begin{array}{c}\text { Non- } \\
\text { pregnant } \\
\text { uterus }\end{array}$ & $\begin{array}{c}\text { Day 7- } \\
\text { pregnant } \\
\text { uterus }\end{array}$ & Liver & Spleen & $\begin{array}{c}\text { Small } \\
\text { intestine }\end{array}$ & Kidney \\
\hline $1.2 \pm 0.3$ & $39.5 \pm 10.1$ & $449.0 \pm 8.0$ & $3.0 \pm 0.6$ & $16.3 \pm 2.7$ & $144 \cdot 3 \pm 28.9$ & $438.5 \pm 31.8$ \\
\hline
\end{tabular}

Values represent the mean \pm s.e.m. for 6 mice and are expressed as $10^{3} \times \mu \mathrm{mol} p$-nitrophenol liberated $/ \mathrm{mg}$ tissue protein $/ \mathrm{min}$ at $37^{\circ} \mathrm{C}$.

\section{Changes during early pseudopregnancy}

As shown in Text-fig. 2, alkaline phosphatase activity in decidualized (left) uterine horns increased dramatically on Day 6 of pseudopregnancy, reached a maximum on Day 7, and rapidly decreased to Day-5 values on Day 10, while the changes in the non-decidualized (right) uterine horns were very slight.

The weights of uterine horns receiving a deciduoma-inducing stimulus on Day 4 of pseudopregnancy increased to a maximum on Day 9, and then decreased on Day 10. Except for a slight increase $(P<0.05)$ between Days 9 and 10 , the weights of the right uterine horns did not change significantly and were always less than those of the left horns. 

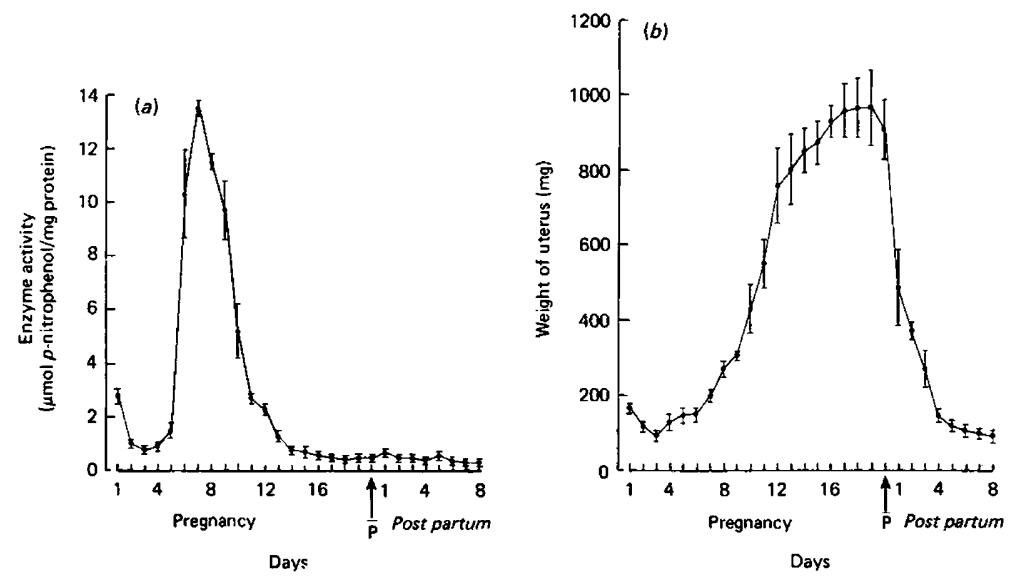

Text-fig. 1. Changes in (a) the activity of alkaline phosphatase in and (b) the weight of the uterus of the mouse during pregnancy and the early post-partum period. Values are the mean \pm s.e.m. for 4 mice. $\mathbf{P}=$ parturition.
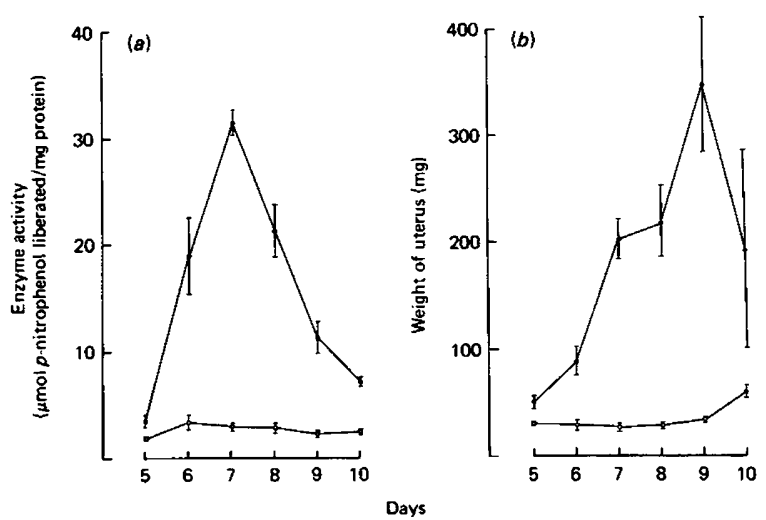

Text-fig. 2. Changes in (a) the activity of alkaline phosphatase in and (b) the weight of uterine horns of mice during pseudo-pregnancy. An oil injection was given on Day 4 into the left uterine horn $(\bullet)$ to induce a decidual reaction; the right uterine horn $(O)$ was not stimulated. Values are the mean \pm s.e.m. for 4 mice.

\section{Alkaline phosphatase activities in uterine homogenates}

(a) In this experiment an attempt was made to determine whether the rise in uterine alkaline phosphatase activity on Day 7 of pregnancy is related to the action of activating or inhibiting factors which may exist in the uterus during the early stages of pregnancy. Homogenates of uteri from non-pregnant and Day-7 pregnant mice were assayed for alkaline phosphatase activity separately and after combination in various proportions. All homogenates were incubated at $37^{\circ} \mathrm{C}$ for $3 \mathrm{~h}$ and assayed for alkaline phosphatase activity at 1-h intervals. The experiment was repeated 4 times with different uterine preparations. The enzyme activity in the uterine homogenates of the pregnant animals was significantly $(P<0.001)$ greater than that in homogenates from non-pregnant animals. Activity values were always additive when the homogenates were combined in various proportions and were not affected by the time of incubation. 
(b) This experiment was to assess whether Triton X-100 exerts any effects on the alkaline phosphatase activity of uterine homogenates, either by a direct action on the enzyme or indirectly through the release or activation of proteases which are capable of attacking the enzyme. Homogenates of uteri were prepared from non-pregnant animals and from mice on Day 7 of pregnancy. Each preparation was divided into two equal portions and either incubated at $37^{\circ} \mathrm{C}$ with no further treatment (Control) or treated with $0.2 \%(\mathrm{v} / \mathrm{v})$ Triton $\mathrm{X}-100$ and incubated at $37^{\circ} \mathrm{C}$. The preparations were assayed for alkaline phosphatase activity after incubation for $1,2,4,8$ and $24 \mathrm{~h}$ and the results are shown in Table 2.

The enzyme activities for the pregnant uteri were about 5 times as great as those for non-pregnant uteri. Triton X-100 had no significant effect on the enzyme activity which remained constant in all preparations for the first $8 \mathrm{~h}$ of incubation and then fell to low levels at $24 \mathrm{~h}$.

Table 2. The activity of alkaline phosphatase in homogenates of uteri from nonpregnant and Day-7 pregnant mice after treatment with $0.2 \%(v / v)$ Triton $X-100$ and incubation at $37^{\circ} \mathrm{C}$ for periods of up to $24 \mathrm{~h}$

\begin{tabular}{crrrrr}
\hline & \multicolumn{2}{c}{ Non-pregnant uteri } & & \multicolumn{2}{c}{ Pregnant uteri } \\
\cline { 2 - 3 } \cline { 5 - 6 } $\begin{array}{c}\text { Time of } \\
\text { incubation }\end{array}$ & Control & $\begin{array}{c}\text { After 0.2\% } \\
\text { Triton X-100 }\end{array}$ & & Control & $\begin{array}{r}\text { After 0.2\% } \\
\text { Triton X-100 }\end{array}$ \\
\cline { 6 - 7 } & $21.2 \pm 2.9$ & $22.4 \pm 3.0$ & & $108.0 \pm 12.8$ & $107.4 \pm 13.0$ \\
1 & $20.0 \pm 3.1$ & $21.6 \pm 2.5$ & & $111.2 \pm 14.2$ & $104.0 \pm 13.7$ \\
4 & $20.6 \pm 2.7$ & $22.2 \pm 2.9$ & & $105.0 \pm 13.3$ & $102.5 \pm 12.9$ \\
8 & $22.4 \pm 3.2$ & $22.3 \pm 2.7$ & & $103.0 \pm 13.7$ & $103.8 \pm 13.4$ \\
24 & $1.2 \pm 0.7$ & $2.6 \pm 0.5$ & & $12.9 \pm 3.4$ & $8.4 \pm 2.7$ \\
\hline
\end{tabular}

Values are the mean \pm s.e.m. for 4 determinations and are expressed as total $\mu \mathrm{mol}$ $p$-nitrophenol liberated after reaction with substrate for $15 \mathrm{~min}$ at $37^{\circ} \mathrm{C}$.

Table 3. Percentage distribution of alkaline phosphatase activity in homogenates of decidualized (left) and non-decidualized (right) uterine horns of mice after centrifugation and the effects of $0.2 \%(v / v)$ Triton $\mathrm{X}-100$

\begin{tabular}{|c|c|c|c|}
\hline \multicolumn{2}{|c|}{ Centrifugation } & \multicolumn{2}{|c|}{$\begin{array}{l}\% \text { Distribution of alkaline phosphatase } \\
\text { activity in: }\end{array}$} \\
\hline \multirow[t]{2}{*}{$\begin{array}{c}\text { Force } \\
(g)\end{array}$} & Fraction & $\begin{array}{l}\text { Decidualized } \\
\text { horns }\end{array}$ & $\begin{array}{l}\text { Non-decidualized } \\
\text { horns }\end{array}$ \\
\hline & & \multicolumn{2}{|c|}{ Homogenates not treated with Triton $X-100$} \\
\hline 500 & Sediment & $26 \cdot 7 \pm 1 \cdot 8$ & $25 \cdot 7 \pm 0.9$ \\
\hline 500 & Supernatant & $73 \cdot 0 \pm 2 \cdot 5$ & $74 \cdot 3 \pm 1 \cdot 5$ \\
\hline 10000 & Sediment & $40 \cdot 7 \pm 2.9$ & $37 \cdot 0 \pm 2 \cdot 1$ \\
\hline 10000 & Supernatant & $57 \cdot 3 \pm 2 \cdot 6$ & $60 \cdot 7 \pm 3 \cdot 5$ \\
\hline 105000 & Sediment & $68 \cdot 7 \pm 2 \cdot 0$ & $69 \cdot 3 \pm 2 \cdot 6$ \\
\hline \multirow[t]{2}{*}{105000} & Supernatant & $28 \cdot 1 \pm 2 \cdot 1$ & $29 \cdot 0 \pm 2 \cdot 3$ \\
\hline & & \multicolumn{2}{|c|}{ Homogenates treated with Triton $X-100$} \\
\hline 10000 & Sediment & $3 \cdot 2 \pm 0 \cdot 1$ & $2 \cdot 8 \pm 0.1$ \\
\hline 10000 & Supernatant & $98 \cdot 3 \pm 2 \cdot 8$ & $98 \cdot 0 \pm 2 \cdot 9$ \\
\hline 105000 & Sediment & $3 \cdot 0 \pm 0.1$ & $3 \cdot 0 \pm 0.1$ \\
\hline 105000 & Supernatant & $98 \cdot 2 \pm 3 \cdot 1$ & $97.5 \pm 3.5$ \\
\hline
\end{tabular}




\section{Subcellular distribution of alkaline phosphatase activity}

The percentage distribution of the alkaline phosphatase activity in homogenates of decidualized and non-decidualized horns of mice killed on Day 7 of pseudopregnancy are shown in Table 3. For each homogenate the alkaline phosphatase activities in the sediment and supernatant fractions were complementary. The activity in homogenates of uteri from mice on Day 7 of pregnancy had a very similar distribution, and have therefore been excluded from Table 3 to conserve space.

Treatment of homogenates with $0.2 \%(\mathrm{v} / \mathrm{v})$ Triton $\mathrm{X}-100$ for $1 \mathrm{~h}$ at $37^{\circ} \mathrm{C}$ prevented the sedimentation of alkaline phosphatase activity, even when samples were centrifuged at $105000 \mathrm{~g}$, and allowed most of the enzyme activity to be recovered in the supernatant fractions. The effectiveness of the detergent for solubilizing the enzyme in uterine homogenates was the same irrespective of the presence or absence of deciduomata.

The results (not shown) of subsequent experiments demonstrated that uterine homogenates need only be incubated with Triton X-100 for $30 \mathrm{~min}$ at $37^{\circ} \mathrm{C}$ to effect the same extent of enzyme solubilization as achieved after incubating for $1 \mathrm{~h}$.

\section{Discussion}

The increased alkaline phosphatase activity in the stroma of the mouse uterus during early pregnancy is already well documented (Finn \& Hinchliffe, 1964; Finn \& McLaren, 1967; Smith, 1973). The results of the present investigation using biochemical assay techniques confirm this observation and demonstrate a 13-fold increase in the activity of the uterine enzyme during the peri-implantation period with a relatively short-lived maximum being reached on Day 7 of pregnancy. The similar response of the enzyme in uterine horns of pseudopregnant mice receiving a deciduoma-inducing stimulus on Day 4 and the essentially unaltered activity in uterine horns not receiving the stimulus further supports the proposal of Finn \& Hinchliffe (1964) that alkaline phosphatase is associated with the induction of the uterine decidual cell reaction in mice. The pattern of decidual growth, reflected by uterine weight changes, in the pseudopregnant mice was similar to that described by Hetherington (1968) and confirms that involution occurs after Day 9.

The factors responsible for the regulation of alkaline phosphatase activity in the decidua during pregnancy and pseudopregnancy remain to be elucidated. The present results suggest that changes in uterine weight and the presence of activating or inhibiting molecules do not appear to be major factors once the initial hormonal priming for the decidual cell reaction has been achieved (see Finn \& Porter, 1975; Yochim, 1975). Furthermore, the enhanced alkaline phosphatase activity in the decidua is not solely a function of circulating hormone because the enzyme activity was not increased in the nondecidualized horn of the same animals. There was some association between enzyme activity and uterine weight between Days 1 and 3 of pregnancy, before the appearance of deciduomata, and the decreases then could perhaps be attributable to diminishing stretch-induced effects on the uterus caused by the accumulation of luminal fluid on Day 1. Decreasing levels of circulating oestrogen may also be involved since this hormone influences both the weight of the uterus and the activity of alkaline phosphatase in the luminal and glandular epithelia (Smith, 1973).

The low and unaltered levels of alkaline phosphatase activity in the blood serum of mice between Days 1 and 10 of pregnancy suggest that there is no appreciable entry of the uterine enzyme into the circulation in mice, although an alkaline phosphatase of placental origin causes increased serum levels of the enzyme in pregnant women (Ghosh \& Fishman, 1969; Fishman, 1974).

Although the distribution of alkaline phosphatase within a particular tissue is not homogeneous, Fernley (1971) has indicated that the enzyme is generally very active in those tissues concerned with the transport of nutrients and is often present in secretory organs and developing tissues. This may also be true for the enzyme in the mouse because we found high specific activity values in the kidneys, small intestine and decidualized uteri and only relatively low values in the spleen and liver.

The alkaline phosphatase activity found in many mammalian tissues is largely associated with particulate material and sediments in homogenized preparations during centrifugation (Fernley, 
1971; Hung \& Melnykovych, 1976). The bulk of the alkaline phosphatase activity in the mouse uterus is also associated with particulate material with only about $29 \%$ of the activity occurring in the cytosol. It is possible, however, to attribute much of this activity in the cytosol to enzyme which could have been released from the particulate fraction during the preparation of the tissue. Although the alkaline phosphatase activity in the mouse uterus is associated with each of the particulate fractions sedimented at 500,10000 or $105000 \mathrm{~g}$, further studies are required to determine the precise relationship of the enzyme with the various subcellular particles. Iritani \& Wells (1976) describe similar fractions prepared from rat uteri as nuclear, mitochondrial and microsomal, respectively, but these are only crude subcellular fractions and each fraction may contain a high proportion of contaminating particles. Therefore, the results simply demonstrate an association of alkaline phosphatase activity with subcellular particles of differing size and/or density and do not necessarily suggest any preferential association with any particular type of particulate material. The proportion of alkaline phosphatase activity associated with the particulate fractions of the uterus remained unchanged when decidua were formed during pregnancy or pseudopregnancy, despite the large increases in the activity of the enzyme which accompany this event. It would therefore appear that the binding capacity of the enzyme to the lipoprotein membranes (Fernley, 1971) of the subcellular particles is not influenced by the decidual cell reaction and that major changes in its subcellular distribution are not required for it to be effective during early pregnancy. These results support the widely held belief that alkaline phosphatase plays a role in membrane transport.

The solubilization of the enzyme in uterine homogenates treated with Triton X-100 provides further support for the proposal that alkaline phosphatase is largely membrane-associated in the uterus of mice. This non-ionic detergent is an effective membrane-solubilizing agent and in recent years has been employed with increasing frequency in the study of membrane-bound alkaline phosphatases (Hung \& Melnykovych, 1976; Ey \& Ferber, 1977a, b). These authors have indicated that the solubilization of membranes with Triton X-100 and other membrane-active agents frequently increases alkaline phosphatase activity, in some cases by as much as $50 \%$. In the present investigation Triton X-100 effectively solubilized the mouse uterine enzyme without influencing its catalytic activity, so it can be concluded that all the active centres of the membrane-associated enzyme are accessible to the $p$-nitrophenylphosphate substrate and are probably not deeply buried within the membrane. Furthermore, the Triton X-100 at the concentration employed in these studies $(0 \cdot 2 \%, v / v)$ neither appears to affect the active centre directly or allosterically nor induces the release or activation of proteases which are capable of attacking the alkaline phosphatase because activity values remained essentially the same in all the samples during incubation at $37^{\circ} \mathrm{C}$ for $24 \mathrm{~h}$.

The enzyme-solubilizing effect of Triton X-100 is of considerable value for our further studies of the biochemical and kinetic properties of the purified membrane-associated and 'free' cytosol forms of mouse uterine alkaline phosphatase to elucidate the role of this enzyme in early reproductive processes.

This work was supported by a grant from the Australian Research Grants Committee. We gratefully acknowledge the skilled technical assistance of Mrs A. Bermingham.

\section{References}

Christie, G.A. (1966) Implantation of the rat embryo: glycogen and alkaline phosphatases. J. Reprod. Fert. 12, $279-294$.

Ey, P.L. \& Ferber, E. (1977a) Calf thymus alkaline phosphatase. I. Properties of the membrane-bound enzyme. Biochim. biophys. Acta 480, 403-416.

Ey, P.L. \& Ferber, E. (1977b) Calf thymus alkaline phosphatase. II. Interaction with detergents. Biochim. biophys. Acta 480, 163-177.

Fernley, H.N. (1971) Mammalian alkaline phospha- tases. In The Enzymes, Vol. IV, pp.417-447. Ed. P. D. Boyer. Academic Press, New York.

FinN, C.A. \& HinchlifFe, J.R. (1964) Reaction of the mouse uterus during implantation and deciduoma formation as demonstrated by changes in the distribution of alkaline phosphatase. J. Reprod. Fert. 8, 331-338.

FinN, C.A. \& McLaren, A. (1967) A study of the early stages of implantation in mice. $J$. Reprod. Fert. 13, 259-267. 
FinN, C.A. \& Porter, D.G. (1975) The control of implantation and the decidual cell reaction. In The Uterus, pp. 86-95. Ed. C. A. Finn. Elek Science, London.

FishmaN, W.H. (1974) Perspectives on alkaline phosphatase isoenzymes. Am. J. Med. 56, 617-650.

Ghosh, N.K. \& FishmaN, W.H. (1969) Characterization of placental isoenzyme of alkaline phosphatase in human pregnancy serum. Canad. J. Biochem. 47, 147-155.

HAFez, E.S.E. \& WhiTe, I.G. (1967) Endometrial and embryonic enzymes in relation to implantation of the rabbit blastocyst. Anat. Rec. 159, 273-278,

HAFEZ, E.S.E. \& WhiTe, I.G. (1968) Endometrial and embryonic enzyme activities correlated with implantation in the ewe. J. Reprod. Fert. 16, 59-67.

HALL, K. (1969) Uterine mitosis, alkaline phosphatase and adenosine triphosphatase during development and regression of deciduomata in pseudopregnant mice. J. Encdor. 44, 91-100.

Hetherington, C.M. (1968) The development of deciduomata induced by two non-traumatic methods in the mouse. J. Reprod. Fert. 17, 391-393.

Hung, S.C. \& MelynKovych, G. (1976) Alkaline phosphatase in He La cells. Stimulation by phospholipase $\mathbf{A}_{2}$ and lysophosphatidylcholine Biochim. biophys. Acta 429, 409-420.

IrItanI, N. \& Wells, W.W. (1976) Properties of a bi- carbonate stimulated ATPase from rat uterus. Biochim. biophys. Acta 436, 863-868.

LeISER, R. \& WILLE, K.H. (1975) Alkaline phosphatase in the bovine endometrium and trophoblast during the early phase of implantation. Anat. Embryol. 148, 145-157.

Lowry, O.H., Rosebrough, N.J., FARR, A.L. \& RANDALL, R.J. (1951) Protein measurements with the Folin-phenol reagent. J. biol. Chem. 193, 265-275.

Manning, J.P., Steinetz, B.G. \& Giannina, T. (1969) Decidual alkaline phosphatase activity in the pregnant and pseudopregnant rat. Ann. N.Y. Acad. Sci. 166, 482-509.

MuRdoch, R.N. (1970) Uterine endometrial phosphomonoesterases in relation to implantation in the ewe and rabbit doe. Aust. J. biol. Sci. 23, 1089-97.

Murdoch, R.N. (1972) Changes in acid and alkaline phosphatase activities in the uterus and oviduct of the rabbit doe during early pregnancy. Aust. J. biol. Sci. 25, 387-396.

SMITH, M.S.R. (1973) Changes in distribution of alkaline phosphatase during early implantation and development of the mouse. Aust. J. biol. Sci. 26, 209-217.

Yоснім, J.M. (1975) Development of the progestational uterus: metabolic aspects. Biol. Reprod. 12, 106-133.

Received 10 February 1978 